Interview

\title{
SUNERA THOBANI: A VERY PUBLIC INTELLECTUAL
}

\author{
Keywords \\ colonialism, feminism, imperialism, socialism, war
}

Sunera Thobani is a formidable activist and scholar. Through decades of activism and scholarship, spanning the globe from East Africa to Canada, via England and the United States, she has developed and applied a critical race feminist and anti-imperialist analysis of world capitalism and colonialism. As an activist, she is probably best known as the former President of the National Action Committee on the Status of Woman, Canada's then largest feminist organization. During her tenure she sought to make anti-racism central to feminist struggles. In her academic work, she has developed critical race theory to cast new light on the dynamics around globalization, violence against women, reproductive technologies, social programmes, immigration and nationbuilding, and colonialism and war. In her research and teaching, she consistently combines her scholarship with community activism, including through her work at the Centre for Race, Autobiography, Gender and Age (RAGA), which she directs and which features active collaboration among community activists and university scholars and students. She is a founding member of the Canada-wide alliance, Researchers and Academics of Colour for Equity.

Sunera Thobani was educated at universities in England, the United States and received her PhD from Simon Fraser University in Canada. She is the author of numerous articles, both scholarly and for a more general public. Arguably her most well-known intervention is "War Frenzy," a 2001 speech calling on women across Canada to oppose the Canadian support of the American-led invasion into Afghanistan. This intervention is now reproduced in a book of Great Canadian Speeches (2004). A frequently invited speaker in both her academic and activist capacities, she has addressed audiences across Canada, as well as in Austria, China, Denmark, England, India, Malaysia, Mexico, the Palestine Occupied Territories, the Philippines, and the United States. Sunera Thobani has co-edited several books on critical race theory and feminism and is the author of the widely-read Exalted Subjects: Studies in the Making of Race and Nation in Canada (2007). Her forthcoming Social Sciences and Humanities Research Council (SSHRC) supported book is 
tentatively titled, Media Representations of Gender and the War on Terror.

This interview was conducted by William K. Carroll in Vancouver, British Columbia in February 2012.

WC: The first question I have for you, Sunera: You're originally from Tanzania and your post secondary education was in London England, Denver Colorado and Vancouver, British Columbia, covering all three of the anglo-American liberal democracies. How did those cross-cultural passages shape your perspectives as an activist-intellectual?

ST: Well, these passages gave me an appreciation for the importance of context, of being very clear about understanding the space that you're in, the environment that you're in and the very different -- even though in fundamental ways, very similar -- social relations in each location and the ways in which they are structured. So they gave me a deep appreciation for context. Moving to all of these places as an immigrant also gave me an appreciation for the importance of communities, of support networks. But the main impact was to give me an international, a global, perspective on issues rather than thinking only within the confines of a narrow nation-state space -- to really appreciate how the commonalities that existed at the international level also existed at the national level, yet had their differences.

I'm very grateful for this internationalist outlook. In many ways of course, it is a very painful experience to be dislocated and to have to relocate so many times and leave members of the family behind at all these various places. So the learning comes with its costs as well. But it gave me this notion of a world much larger than my community, than the country I lived in and my politics were very profoundly shaped by this experience.

WC: Is there any sense of the north-south, the contrast, experienced through these crosscultural passages?

ST: Very much so, yes. Moving from East Africa to England, for example, was a huge shock, also very traumatic in different ways, especially coming face to face with the incredible inequalities that exist in both sites. But every time I travel to any country in the global south there is a feeling of being home, of familiarity and recognition, despite all the problems and recognizing the intense inequalities. There is a level at which that seems much more real than living in the global north, where certainly, poverty exists -- there is no question about it and it is very wretched kind of poverty -- but it's not quite as intensely visible and localized. So in all the countries in which I have lived have been so different, but the north/south divide is clearly very much there.

At the same time, all these dislocations and relocations gave me an appreciation, even within the north, of the existence of the south, particularly among immigrant 
communities, especially undocumented migrants. I have been very closely and personally connected to how they survive in this environment. Of course, coming here to Canada has also meant seeing and experiencing what it means to live in a settler colonial society and learning about the status of Indigenous peoples here.... So, it has given me an understanding of the global divisions between the north and south, while recognizing that the south very much exists in the north. And when I travel to, say, East Africa, I see also how the north exists in the south.

WC: You arrived in Canada in 1989. Just four years later, you were elected president of the National Action Committee (NAC) on the Status of Women, the first woman of colour to hold that office. That in itself seems remarkable: to arrive in a country and four years later be elected president of its major feminist movement organization. Looking back on it, how would you tell that story?

ST: I would tell it quite differently, actually, because the way that it gets told in Canada, is, "You arrived here, four years later you are a president of this organization...."

WC: (laughs). Like I just said.

ST: What it erases is my history of being an activist since the ' 80 s, for over a decade before I come to Canada: I was an activist in the anti-racist movement, in third world solidarity movements, in the anti-apartheid movement, and in the women's movement as well, working with South Asian women's organizations in the U(nited) K(ingdom). In the U(nited) S(tates), when I was a graduate student, I was very much connected to the anti-nuclear, peace, Palestinian solidarity movements... When I was living in England, as a student, I actually went and spent a year working as a volunteer in Palestine. All of the experience and expertise that I had gained in doing this kind of work got erased in Canada when I became the President of the National Action Committee on the Status of Women. It was as if suddenly everybody was asking, "Who is this outsider, come from nowhere and wants to be...?" That is one part of my experience as an activist that the question erases. The other part of my experience that it also erases is my activism in Canada: When I came to Vancouver, immediately I joined almost every women's organization in the city. I wanted to find out what the political environment was like, what women's movement politics were like here, what issues they focused on, and through that work, of course, I very quickly became aware of NAC. And I started being involved in NAC, very early -- as soon as I came to Canada, in fact. Through that, I became connected to women of colour activists in Ontario, in other parts of the country, in Quebec. So I was already participating in developing those networks before I became President of NAC. 
The decision for me to run as the president of NAC was not a personal decision; it was a collective decision that was made by the Women of Colour caucus within NAC. So the existence of that really strong caucus also gets erased in the story of "me arriving and four years later I'm president", because, of course, the history of women of colour organizing within NAC is much, much older. The Women of Colour caucus made the decision that it was time that we should run a candidate for the president. We looked at all everybody that was there who could carry the position, who could win an election, because all of us were preparing for an election. And even though there were women with much more experience than me in Canada, they were not willing to be nominated. It came down to just a couple of women in the Women of Colour caucus and most of them were hesitant, because they didn't have a national presence. And through my work, particularly against the opening of the sex selection clinic here in Vancouver and the Royal Commission on Reproductive Technologies, the work I'd done around violence against women when the Blue Ribbon Panel was appointed by the government.... I had somewhat of a national presence because of the media attention that I had received. And as I say, I had built networks across the country, so I knew that if I was to run in an election, I stood a very good chance of winning.

WC: As NAC President, you followed Judy Rebick, herself a transformative leader. Judy was well known as an ardent socialist-feminist; you brought a politics of anti-racism to the women's movement. What was the relation between these two moments of political development, what were the challenges for you and what do you see as the legacy of your time as President of NAC?

ST: I think Judy's socialist-feminist commitments made her aware and open to addressing issues of race, and for me, coming from an anti-racist perspective, I knew that race politics are class politics. If we look at the global international division of labour it becomes very hard to make the case that anti-racist struggles are not also class politics, and this is also the case if we look at the class composition of immigrant communities...So for me there never was a contradiction between race politics and class politics. In fact, for me, class politics alone didn't go far enough and were not adequate to the task of transforming society in the way that they wanted to, if they did not take race politics into consideration. So really there was no disagreement between Judy and myself about the importance of looking at the intersection of gender, race and class. I think Judy had a clear understanding that that was very important and for me, class was very central to my anti-racist politics. One of the things that I am most pleased about was that during my tenure NAC actually organized the cross-Canada Women's March Against Poverty. I couldn't see poverty as not being a race issue: it clearly was. So, there really wasn't much of a contradiction. 
The biggest challenges really came from the investments in whiteness that many of the activists inside NAC continued to have. I think I had in some way underestimated the strength of those liberal feminist networks within NAC and in the feminist movement generally. Certainly, Judy was able to articulate a politics that I was much more comfortable with and I did think that she represented, or at least her politics represented, a majority position within NAC -- and I found out that really wasn't the case. So the challenge was the investment in whiteness that was quite deep in the women's movement. Many of the women of colour activists that I was working with at that time, who had been in NAC longer, had also thought that the investments were much lesser than they turned out to be.

I think another big challenge was that with Judy's presidency, NAC came as far as it could go in terms of electoral politics. We organized during the Referendum on the Charlottetown Accords to say 'No' and Judy led that campaign very well, very eloquently, very powerfully and of course, the referendum didn't pass. But in that, NAC came as far as the women's movement could go in terms of electoral politics, especially at a time when social democratic parties were turning to the right much more than anybody had expected. While all social movements were confronting these changed political priorities, inside NAC that became a really big question: so what do you do next? My response was to turn to building the movement from the ground up. There has to be a transformative vision that articulates a politics that goes beyond the issues within the space of electoral politics. Not that electoral politics are not important, they are, and the first campaign we organized was for the upcoming federal election, right after I was elected as president. But, for me, it was very important that we had a longer term vision. And as you know, NAC and the women's movement in Canada has been very state focussed, much more so than women's movements in other parts of the world. I did think that was a mistake.

WC: And, at one time, NAC was state funded.

ST: Exactly. It was state funded. I came from spaces where women's organizations were not funded by the state, and so the question always for me was: if a movement disappears when the funding disappears, what kind of movement is it anyway? So that was the question I tried to raise and of course, I tried to diversify NAC's fundraising. Not very successfully, I might add, because there was a great deal of resistance from within the organization. And I understood the position that NAC did important political work and that women are a constituency that are not fully represented within society. There is an argument to be made for government funding as a right of citizenship, as a right of participation --of women's participation within the polity. So I certainly recognized that argument and I think it is a very important one to make. 
But I also knew that the way things were going, it wasn't going to be enough to keep making that argument. We had to think differently, creatively. For me, building coalitions on the ground, transforming feminist politics so that anti-racism was central, really highlighting the struggles of Indigenous women, doing a lot of alliance building with Indigenous women -- those were the things that I thought would bring about the lasting change, would actually help the women's movement develop a more transformative, anti-colonial politics in terms of Indigenous women's struggles. That is what I saw as the role that I could play in NAC.

WC: Since 1996, you have taught women's studies at Simon Fraser University (SFU) and from the year 2000, at the University of British Columbia (UBC). Yet before your term as NAC president, you taught at Evergreen State College in Washington, a liberal arts institution known for innovative and even radical pedagogy. What was Evergreen like when you were there in comparison with SFU and UBC and were there any things that you took from Evergreen for future reference in your teaching?

ST: Evergreen was a very, very different institution from SFU or UBC for that matter. Faculty there, at least the programmes that I was connected to, were very committed to issues of social justice. I must say I haven't found that in any Canadian university department! (Laughs). And the faculty were also committed to doing things differently, in their practice, not only in pedagogy in the classroom, but in terms of hierarchies within programmes, within departments, within the institution. Team-teaching was an important way for them to work. It allowed each faculty to bring their strengths, for faculty to learn from each other even as they were teaching. I miss that focus and that kind of integrative approach to teaching. We all claim to be interdisciplinary, which is important -- I certainly fight (laughs) to make sure that my work is recognized as interdisciplinary (it tends to be treated as 'activism'). But there is not much thinking in terms of, "How do we actually make interdisciplinarity real and how to we build a work environment and a work culture that promotes that kind of intellectual exchange?" So, for me Evergreen was a model where faculty actually engaged with each other intellectually in terms of their political commitments. Through the programmes, you got a sense of, not only are the students learning and benefiting from this process, but faculty are also doing so, and in many of the same ways that the students are. That for me was very exciting.

Overt commitment to social justice and overt commitment to thinking about teaching differently, evaluating students in a different way, in a more collaborative, respectful way... All of those things were important to me. Of course, that was not the case, unfortunately, at either SFU or at UBC. So it really helped me to develop my own ideas about my pedagogical practice and what kind of relationships I wanted to engage in 
with students. And then, of course, at SFU my position was an endowed chair so I was a visiting scholar in a women's studies department, and at UBC it's a position in women's and gender studies. But these are both much more hierarchical institutions, much more invested in the elitism that universities tend to be invested in, much less tolerant and much less supportive of public intellectuals. They do not value activist scholarship, defining that as a liability rather than as a real asset and as an important thing for departments to value. So that has been very different to deal with. To be labelled an activist or a public intellectual is treated as a very negative thing, which for me is very hard, even now, to come to terms with.

WC: Let me ask you some questions about the 9/11, 2001 attacks on the United States. The cliché about $9 / 11$ is that it changed everything. Yet, in the immediate wake of $9 / 11$, you gave a speech just as the US, with its assembled allies, was beginning its bombing and invasion of Afghanistan. You stated, to quote from that speech: "US foreign policy is soaked in blood and other countries in the West, including, shamefully, Canada, cannot line up fast enough behind it. All want to sign up now as Americans and I think it is the responsibility of the women's movement to stop that, to fight against it". Yours was a brave and prophetic intervention. But that speech became a lightening rod for moral panic. You were widely vilified in the corporate media. My first question is: What did the reaction tell us about the organization of power and knowledge in this era of renewed imperialism? The second is: When you take such a bold, radical stance, speaking truth to power, putting yourself so far out of step with hegemonic politics, how do you cope how did you cope -- with the backlash personally?

ST: I'll take the first question first: What did it reveal? The first thing it revealed to me was how deeply embedded a kind of racial logic was both within the state and in social movements, including the women's movements, sadly to say. Throughout the 1990s we had struggled very hard against the restructuring of the welfare-state. We had worked to reveal the links between the right-wing anti-woman agenda and the right-wing antiimmigrant agenda. We had highlighted how immigrant women were at the intersection of these really ugly politics, on the basis of which we saw the rise of the Reform Party, for example. There was a public space where those perspectives could be articulated -- even in the corporate media, to some extent. Of course, the corporate media has never been friendly to those kinds of radical politics, but we had managed to shake up some of the discourses around Canadian nationhood, around racial politics, around the antiimmigrant agendas. The aftermath of $9 / 11$ showed how fleeting that moment had been, how precarious that space had been and, more disappointingly, how little we had actually managed to change the women's movement in this country. 
The intense Islamophobia that erupted right after the attacks was incredibly difficult to witness, especially the role that women activists played in fuelling that Islamophobia by giving it a gendered legitimacy, by focussing on the quote unquote "oppressed Muslim women" and by resuscitating old, discredited colonial constructs of the veil and of Muslim communities. It was a profound learning lesson for me about how fragile the changes had been that we had made through our anti-racist, feminist, radical politics. 9/11 revealed how quickly the discourse could be changed and how quickly the women's movement could ally itself with the state and with the nation in global politics. So in a way, yes, 9/11 did change everything. But not quite in the way that the mainstream media presents the case.

The intense Islamophobia which has since then become much more institutionalized, much more integrated into public culture and public spaces, really did change things tremendously, in a profound and destructive way. The response from states, nations, women's movements -- that has changed everything. The securitization, a racialized form of securitization, of the nation-state that has taken place, the militarization....All of the social justice movements have to think very carefully about the role that they have played in legitimizing some of that discourse and these changes, and they also have to think about where the points are at which they have tried to disrupt this discourse.

WC: How did you cope with the backlash, the personal attacks?

ST: It was an ugly moment. One of the ugliest in my life. It did take a huge cost both on me, and of course, my family. My mother was with me at that time, it was painful for her, and my daughter was very young at that time. Of course, I also had to deal with the announcement by the RCMP to the media that I was being investigated for a hate crime, I had to make sure that I was not vulnerable to a charge like that legally. I did have some support, which was gratifying and important. Some of my faculty colleagues did stand up clearly for me and they did support me in important ways. There was some level of public support. Not very much from the mainstream... but a lot from immigrant communities. I think it was the letters that many people wrote to the University and the media that saved my job because the corporate media, particularly in this city, was on a campaign to get me fired. When I look at the Vancouver Sun, for example, and their coverage, there was a very clear push to get me fired from my position -- I was untenured at that time. But there were also some journalists in the mainstream media who did try and change the discourse. One important intervention was reframing the issue as a matter of academic freedom. In the long term, it's not where I would have chosen to take that speech but it was important for the people who did. So I did receive some support from unexpected 
quarters, mainstream journalists. But very few. Not the feminist ones -- they wouldn't do anything.

WC: In that 9/11 speech and in subsequent writing, you've emphasized the links between racialization, including Islamophobia and imperialism, but also the ways in which liberal feminist discourse -- for instance, the suddenly urgent need to liberate Afghan women from patriarchal traditions through schooling -- can play an important ideological role in recruiting support. Can you speak more broadly about the legacy of liberal feminism for feminist politics in both global north and south?

ST: Liberal feminism has been a project of integrating women into global capitalist relations. I can't understand liberal feminism as anything other than that. I see it as very much part of the status quo. I recognize that historically liberal feminists had to struggle to get their own piece of the pie, but they are very happy to hang on to their piece of the pie! (Laughs). So I see liberal feminism as very much an integrative politics, of wanting to discipline women into existing systems and structures, reproduce the status quo. In terms of the other feminist traditions, after 9/11 it really was a shock to see how much they were also invested in many of these status quo politics. For example, I don't think that socialist feminists have done anything much to stand up to Islamophobia, I don't think postmodern feminists have done anything to confront Islamophobia. Instead, they have given legitimacy to the notion that this highly militarized, neoliberal state might have some feminist commitments at a global level in fighting Muslim men's alleged misogyny. They have given imperialist politics a feminist face and legitimized the claims that were being made by the state, like, "Canadians are in Afghanistan only so that women and girls can go to school." If every feminist activist in this country had taken a stance against it -which they didn't -and I'm not saying that it would have stopped the invasion in Afghanistan, that it would have stopped the occupation. Clearly I don't think it would have. But that feminist acquiescence to Islamophobia, and sometimes even active feminist promotion of Islamophobia, managed to give the state legitimacy, give the War credibility, and also helped to mobilize public support for the War. So I do think that the politics of liberal feminisms are very harmful and very damaging, particularly to groups of women who are really marginalized in society and who experience the worse effects of the global capitalist system that we live under. But I think many of the other feminist traditions of whom we might have expected something better have not been much different. 9/11 and the war on terror has dealt anti-imperialism feminist politics a very strong blow - and I would include anti-racist politics within that larger framework of anti-imperialist feminisms. 
WC: We've been talking about imperialism, which is a critical concept that figures significantly in your work. This is a term that has borne multiple meanings and one that is sometimes dismissed as empty rhetoric or as having been superseded by post-imperial hybridity or the BRICs, the emergence of Brazil, Russia, India and China as global economic powers. What do you mean by imperialism and how does that understanding contribute to its continuing analytic value?

ST: I use both imperialism and colonialism centrally in my work. I use imperialism in the Marxist understanding of that term. It refers to what others call post-colonial societies, third world societies that actually did acquire national independence -- which turned out to be a very limited kind of independence. The global north or the previously colonizing powers continued to dominate their economies and those countries were integrated into a very unequal hierarchy within the global economy. So that's the sense in which I use imperialism. But I'm also very cognizant of how limited the Marxist definition of the term it is when we look at settler societies like Canada and the United States, where colonialism remains ongoing. There has been no process of decolonization of Indigenous peoples in this land, North America. So colonialism remains important to think through for contemporary politics. Of course, colonialism is central to how I think about race as well. The mutual constitution of coloniality and racialization is central and I don't see colonialism as having been ended in any sense, even in the countries where national independence was achieved. So I use both colonialism and imperialism in a very unsatisfying and frustrating way.

But I do think that the moment we are living in right now is something different. We are seeing legitimizations of occupations and invasions, in Iraq, in Afghanistan, in a way that many activists and intellectuals had thought was over. There was a sort of recognition that yes, the settler settlers were still shaped by ongoing colonialism, but the idea was that in the global south something had changed. The invasions and occupations in Afghanistan and Iraq showed how much coloniality still remains a part of the agenda of globalization, of economic restructuring. So, I use both imperialism and colonialism very closely together in my own thinking and I also get frustrated at their inadequacy, really, in terms of capturing what is happening in the early 21 sst century. The nature of the state is changing and the war of terror has revealed that many, many things that intellectuals and activists had consigned to the past are re-emerging and taking centre stage in global politics...

WC: In your speech last September, "Reflections on the Tenth Anniversary of 9/ 11", you called attention to the complete lack of self-reflexivity on the part of mainstream media and political leaders commemorating 9/11. You also emphasized the emergence of a new imperial model that now includes supporting rebel groups and political forces in Arab 
Spring countries that will thwart revolutionary change. You point to a convergence of left movements and parties in the West around a shared Islamophobia, targeting in particular, "bad Muslims" who resist US imperialists. This is all a pretty grim scenario, from a social justice perspective. As you observe and act within the developing situation, do you see any openings for anti-imperialist politics that might be transformative?

ST: Yes, I do see a possibility for an anti-imperialist politics that are clearly transformative. I mean if we look at what is happening in the "Arab Spring" clearly these are movements that are committed to a deeply transformative vision. There is no doubt about that. I think that the anti-war movements in the West have some kind of transformative politics. Also, for me however, race is one of the founding blocs of capitalism, of modernity, of the global order as we are experiencing it today, of questions of sovereignty, power, subjectivity and nation-state formation. Race is foundational to all of these phenomena and entities and structures and systems with which we live. If race doesn't emerge as central in a transformative vision, if race is not addressed, it poses very serious limits to transformative politics. And when I say race, I think that Islamophobia is an articulation of race politics, it is a racialization of Muslims. So that when we talk about Muslims today we know that in practice the category doesn't only apply to practicing Muslims. Instead, "Muslim" is used to apply to black and brown bodies. The young man who was shot by British security services in London was Brazilian but he was described as 'Pakistani-looking'. So we know that the ways Islamophobia gets articulated the ways it actually targets black and brown bodies, for surveillance, for the harsh measures of the security state, means that Islamophobia is a discourse of racialization of our times.

If I look at the Middle East, at what is happening right now, if the relations between race and the global order are not addressed front and centre in politics, then I don't think these movements are adequate to bringing about the transformative politics that people there want to bring about. When I looked at how what is happening in Egypt is being discussed here, a lot of left activists were very determined to label the Arab Spring as a class revolution -- and claim that the Muslim brotherhood might hijack it (laughs). That it really is only class politics that were being articulated on the streets. But these activists define the politics as such without engaging with the politics of the Muslim brotherhood, for example, or without understanding where that movement come from, or what was transformative and revolutionary about their vision. Without actually engaging with it, the left analysis becomes yet another moment of mislabelling, a failure to deal with the question of difference, a re-inscription of their Eurocentric politics. .

I think that the struggles in Egypt, in Syria, in Libya, all of them were at heart also about sovereignty. So how do we understand sovereignty in this global order? The occupations and invasions of Afghanistan and Iraq showed very clearly how utterly fragile sovereignty is in what used to be called the third world. It's a big mistake for 
political movements and activists not to understand this relationship between race and sovereignty if they are to have a transformative politics.

WC: Let me refocus and bring the discussion closer to home, as it were. In 2007, you published an important book, Exalted Subjects: Studies in the Making of Race and Nation in Canada. In it, you showed how the creation of a white Canada was based both on the colonization of Indigenous peoples and in the active exclusion of non-Indigenous racialized peoples from territory claimed by the Canadian state, at least up until the late 1960s. How do you assess the prospects for and importance of anti-colonial struggles from within Canada today and what are the difficulties facing Indigenous communities and movements as agents of change?

ST: In terms of anti-colonial movements in Canada, the Indigenous movements for sovereignty, are clearly that -- for land rights, for cultural integrity, against violence against Indigenous women, for example. I see all of those as part of the anti-colonial politics and anti-racist movements of Indigenous peoples. So, for instance, the disappeared and murdered women on Vancouver's downtown east side, I see that not just as an issue of violence against women. As Indigenous feminists have argued, sexual conquest and sexual violence is at the heart of the colonial project. The violence that is being done to Indigenous women on the downtown east side in Vancouver is part of that project of colonial violence playing itself out. I think coloniality is around us everywhere in Canada, literally on the land that we live and work on.

The biggest challenges to anti-colonial struggles in Canada are the pressures on Indigenous peoples for assimilation, the move to introduce private property, for example, in Indigenous communities, and open up resources that are claimed by Indigenous peoples to corporations -- and to do this in the name of improving the lives of Indigenous peoples. Those are among some of the most serious challenges to anti-colonial politics today, the pressures on Indigenous peoples, the coercion on them to assimilate, to extinguish their inherent title and inherent rights, to integrate into the corporate, neoconservative led capitalist economy we are living in today. And of course for me, coming here as an immigrant, the questions have always been: What is my place in this space? What is my responsibility? What is my location in this society? Anti-colonial politics for me then means a politics of alliance with Indigenous women...

WC: Since 2008, you've been directing the RAGA Centre, the Centre for Race, Autobiography, Gender and Age, which is housed at the UBC. RAGA fosters "interdisciplinary, critical race and feminist scholarship with a focus on auto/biography in its broadest interpretation. RAGA also works collaboratively with community organizations to promote social change, based on principles of equity and social justice" 
(www.raga.ubc.ca). My question is: How does this major element of your work life fit with your overall intellectual and political practice?

ST: It fits in quite well I think. I've always struggled to maintain a balance between my work in the university, my academic work and then the work that I do in the community outside the academy. I define my scholarship as activist scholarship and it's a struggle to maintain that balance, especially in institutions that do not really reward you for it, that actually punish you for it. So I took on the RAGA centre when a colleague retired. She was very interested in autobiography studies, and so she had set up the SAGA centre with its focus on autobiographical studies. When I took it over, I wanted race to be a central focus. I wanted RAGA to be a place, a centre on the UBC campus, that would put a priority on developing links with the community outside UBC, that would partner with community organizations in all of its activities and events. For me, it was a question of making the university and its resources accessible to communities that don't have access to them otherwise, and at the same time, take the university (or RAGA) into the community. We have organized as many events in the community as we have on campus - so, the idea was to have a two-way exchange and open up the university space for community activists to come and work with us here. In terms of working practice, every event that we organize has community partners and we have developed a really good network of doing work like that. So RAGA was a space where I could carry on with that type of activist scholarship.

It still remains a big challenge to get a centre like that valued. We have to raise money for everything that we do since we don't get any funding from the university. So everything that I do has to be self-sustaining...it takes up a lot more time because the university's resources are not there in terms of facilitating this work. There is also a problem in getting it recognized as legitimate work. Colleagues are often seeing RAGA activities as nothing to do with service to the university, or nothing to do with the department's work, which is much more important. So it has been a real struggle even to keep the RAGA centre going.

But it has given us a space, it has opened up a space. One of things that I wasn't expecting was that graduate students from across the campus wanted RAGA to be a space for them. So we have a graduate student research network because scholars and also students of colour and of Indigenous ancestry are extremely marginalized in their own departments. They are ill-served by these departments, including departments like women's studies, where one would not expect to see the same problems. But even they're deeply embedded in the departmental culture and in the institutional culture of these universities. So, RAGA has created that space not just for faculty like myself who are engaged in activist scholarship but also for graduate students. And it's become a sort of home for them as well. 
What has been most important in RAGA for me is to create a space where Indigenous scholars and students and scholars of colour and students actually come together and have an exchange, a dialogue. It's a space where we can hear each other's perspectives and engage in dialogue that I hope will lead to something fruitful in terms of really strong alliances being built across the racial divides that exist between Indigenous peoples and peoples of colour. So for me RAGA has been a very important space for doing that kind of work, alliance building, promoting our scholarship, networking, creating spaces where those of us who find it hard to breathe in our own assigned spaces can come together. RAGA has been important to me for that reason as well.

WC: You were professionally trained as a sociologist but your work is highly interdisciplinary -- though clearly in tune with a critical sociological imagination that explores the articulations of history and biography, of the personal and the public and so on. How do you, at mid-career, relate to the division of academe, including social science, into distinct disciplines? Do you see interdisciplinary work as complementary to the disciplines or perhaps as subversive of them?

ST: I think it is subversive of them. That's how I experience it. But interdisciplinary work is in the best traditions of scholarship, the best traditions of learning. I clearly fall on that side of the debate. Having said that, though, I think interdisciplinarity has become a fashionable term now. Everybody claims interdisciplinarity without much grounding in it. For me, political economy has to be a central part of that interdisciplinary training. That is what I strive to give my students: an interdisciplinarity that is grounded in a sound political economy. Political economy itself, of course, is an interdisciplinary approach. But I am surprised how many colleagues who do interdisciplinarity do not engage at all with questions of capital, of labour, with the whole political economy framework. I don't know how one understands the global order in the absence of an interdisciplinary approach that integrates political economy into it. I'm a bit old fashioned about that. (laughs)

In women's studies programmes and in women's studies generally, feminist political economy has pretty much disappeared. For me, it remains very disturbing that I can get fourth year students having gone through an interdisciplinary programme of academic and intellectual training, and at the end of it, they are unable to define neoliberalism, or globalization. That becomes a shocking experience. It makes one suspicious of this new fashionable approach to interdisciplinarity that's becoming popular in universities, but it is an approach that remains completely oblivious of the major structures, systems and institutions of power that shape the social world. 
WC: Let me ask you about another 'inter' word: intersectionality. Intersectionality is another very influential approach in feminist theory and practice. What does it mean to you and are there problems with the way that intersectionality is pursued in some academic circles?

ST: Yes, there are problems with the term because there's the same kind of tokenizing that's happening. Intersectionality can be a powerful articulation of how social relations shape and sustain each other. There is a debate about whether we think about intersectionality as the meeting point for different systems of exploitation and oppression, or whether we think of these as interlocking systems that actually shape and sustain each other. This is a debate where 'interlocking' is defined as a more in-depth understanding of how social relations are organized. Then there is also the question of the constitution of subjectivity, and how and whether intersectionality can contribute to an adequate theorization of this. But notwithstanding these debates, clearly intersectionality developed initially by Black and women of colour feminisms - has made a huge contribution to scholarship. Yet it has become trivialized recently as it has been taken up in Women's Studies. It doesn't ground itself in a strong enough appreciation of social relations, particularly those of class and race, in this area of scholarship, which still remains stubbornly white woman oriented.

And we're living through a very strange moment when we think about intersectionality, because at the same time that intersectionality became very influential, we have also had the emergence of anti-oppression studies. Anti-oppression studies developed mainly by white feminists and activists - was very popular in women's studies but I've always found the anti-oppression framework to be deeply problematic. Every form of social relationship gets equated with every other, so anti-oppression, every form of oppression and exploitation, --including racial -- comes to stand for everything else. There is then a dilution of the rigour and work that one needs to do to understand the intersectionality of social relations. So I have been very sceptical of anti-oppression studies and when I look at intersectionality today and how it gets used, it comes to stand in for people who do anti-oppression work. So there isn't a strong theoretical understanding of these different social relations and how they intersect with - and ground - each other.

Intersectionality was something that was forwarded by feminists of colour, black feminists in particular. Anti-imperialist feminists also used intersectionality as an approach. The response to that from a more liberal and white framework was antioppression work, which completely diluted the power of intersectionality and the interlocking analysis of social relations. So intersectionality gets invoked as a stand-in for anti-oppression work. But the two are very different: there are very different kinds of 
political investments that shape both of those particular concepts and pedagogical practices...

WC: What is your take on feminism today?

ST: Oh dear! (laughs).

WC: It seems that the three genres of second wave of feminism, liberal, social and radical, have either been institutionalized or transformed beyond recognition. What is your take on the challenges and possibilities of feminism? How does the critical feminism you developed with your collaborators, Dr. Sherene Razack and Dr. Malinda Smith, in States of Race speak to these challenges and possibilities of feminism?

ST: I must make a distinction here. When we talk about second wave feminism, when we talk about liberal feminism, socialist feminism, radical feminism, these are very much strands of Western feminism and Western feminist movements. Critical race feminists have a very different story to tell and it doesn't fall quite so neatly into liberal socialist or radical feminism, or first-wave, second-wave, third wave. The story to be told there is of anti-colonial feminists, black feminists for whom the struggles against slavery and its ongoing legacy and impact in the lives of black communities continues to remain central, and anti-imperialist feminists for whom the, north-south divide and imperialism continues to remain central to their politics. We have a very different story to tell than the advance from "first wave, second wave, third wave feminism." There is a much stronger, a much longer continuity around these strategies, around the alliances that we've tried to build. These are very different from the Western feminist stories, as they get told.

Of course, other social relations are central too, but I do think that race is foundational to the global order, to colonialism. So critical race politics has the capacity to develop a much deeper, more profound analysis of the current social world in which we live -- I see greater potential here. I'm not saying that critical race scholarship and feminism can't also be co-opted, but we are nowhere near that situation right now. Critical race feminist scholarship and anti-colonial scholarship actually disrupts this category of the West. This is absolutely vital and politically urgent in the moment we live in, because the war on terror has tried to suture over the fissures that multicultural politics gestured to: claims of white supremacy that were destabilized by civil rights movements, by the immigrants' rights movements, by third world struggles for independence. These movements actually split apart this whole category of the West and discredited ideas of white supremacy, of Western superiority. In a way, the war on terror is re-stabilizing the global institution of white superiority and Western cultural and economic domination. 
The feminist traditions that you've named, liberal, socialist and radical, because they all work within the framework of Western feminism, however much they contest what the meaning of the West is, they haven't broken away from the very category of the West. So they continue to be deeply shaped by that Western worldview and are invested in the paradigm of the West in a way that critical race feminist scholars and activists are not. I see greater potential for radical transformative politics being articulated by those movements than I see coming from Western feminism.

One of the chapters in the book that I am writing right now looks at Western feminist responses to the war on terror. I look at liberal feminist responses, socialist feminist responses and post-structural, post-modernist feminist responses, and truth be told, there is very little that is different about their foundational assumptions. Their political commitments and engagements are different, clearly: some of them opposed the war, others have celebrated it as necessary and even argued for its expansion. But when we look at their foundational assumptions, including their foundational assumptions about gender and gender politics, these are very heavily invested in Western paradigms and Western world views. I don't see signs of them breaking away from that anytime soon.

The political space in which I see transformative politics being articulated is critical race politics, anti-colonial feminist politics and Indigenous women's politics. Because their politics are invested in the transformation of the West, which is arming itself, rebuilding its alliances, rebuilding state-nation relations that were really weakened by the whole restructuring of the welfare state, by the changes that we saw in the 1990s. In the '90s, Western populations were much more dissatisfied, much more against privatization, neoliberalization. Social movements were very clear about opposing that neo-liberalist order. But the Islamophobia that has since reinvigorated this project of the West has derailed these oppositional politics and perspectives.

WC: That leads on to the next question about the Occupy movement. This is an example, perhaps, of transnational grassroots politics from Egypt through Spain, last summer, to New York and many cities around the world last fall. Does the Occupy movement represent a new current, a new left? Is there some connection to the destabilizing of the West and to some of the issues raised by critical race feminists?

ST: I would not equate what happened in Egypt with the Occupy movement in North America. There is something very different going on in the Middle East and in the Arab Spring -- the next step in the politics of the decolonization movements of the 1940s, '50s and the ' 60 s in those countries. So I would have a different approach to what is happening in the Middle East, and in Egypt, countries like that in the 'South', compared to the priorities of the Occupy movements in the global North and the politics that they 
represent. And as many other commentators have noted, I would begin by problematizing the lack of Indigenous participation in these movements, of people of colour and raise the issue of the deeply problematic way we think about "occupy". This is one of the Occupy movement's biggest failings, from my perspective, its lack of anticolonial and anti-racist politics. There was a conflation of all these communities.

But the Occupy movement is nevertheless something new: it is the first time in my activist life in the global north that I have seen a movement emerge and there is no defence made of the system by political elites, by media elites, in short, by the intellectual elites. In fact, you had politicians saying, "Oh yes, I feel my heart is with them, but this is not the right way to go about it." This was the first time that there was no defence of the system coming from anywhere. That was an important moment of rupture. It represents something really important and powerful that needs to be thought through very carefully by intellectuals and activists who are involved in these movements.

And that wasn't the case in the 1990s, with the economic restructuring, the cutback of social services, the dismantling of social programmes. There still was a "Pick yourself up by your bootstraps and the system will work for you" ideology that was being articulated strongly in the media. That was not the case this time around. It signifies something different. We need to think through how to make use of that change.

The other thing I noticed about the Occupy movement was when listening to people speaking in the media, in phone-in programmes, etc. I listened to a CBC open line programme when the Occupy movement first started and there was a woman who phoned in and said "I live in Langley. I am a single mother, I have three children. I can't come to the Occupy movement but those people are there for me, they represent me." There was even a lawyer who phoned in and said, "I'm not going to be there, but those kids are speaking for me too." That kind of ownership from a middle-class constituency is also something that happens very rarely. So that was very different in terms of the kinds of political energies that could have been mobilized by this movement. It's too early to say what will happen. I'm not sure where it will go or where it leads and I'm not sure what role other social movements will play in supporting or containing it, or the ways this politics will get articulated. I'm not sure how the key activists in Occupy Vancouver will articulate their political visions and what they see as transformative in their politics. We've yet to see. But immediately, it was clear to me that this was the first time that there was no defence of the system and that was something quite profound that we need to come to terms with.

WC: Finally, let me ask about your take on socialism. Many people would say socialism is a dead letter, citing the atrocities of Stalinism, the bankruptcy of social democracy and the atrophy of the new left initiatives such as socialist-feminist. Some academics and activists since the 1970s see the very positing of an alternative to capitalism as a problematic, totalizing move. But there are also indications of renewal, such as in Latin America. It's a 
big question, but what is your view on these issues and the prospects for a $21^{\text {st }}$ century socialism?

ST: Socialism is on the agenda in a way that it hasn't been in the last decade or so. The movements in Latin American you mentioned have a socialist vision, but this is also a very strong anti-imperialist vision. The changes in Latin America are creating a space for Indigenous politics to be addressed in a way that socialism is not traditionally engaged with. So there is a lot more happening in Latin America than just the resurgence of a socialist politics. I've always seen socialism as the most radical politics coming out of the West. But I've never seen as it as completely adequate to being able to respond to the visions of other movements in other parts of the world. Certainly, I've always been interested in the socialist vision and Marxist politics and clearly it's been formative to my own politics. But I've never been convinced that it is enough of a vision; I don't think it is. Unless, again, socialism can come to terms with coloniality, post-coloniality, however we define it, and of course, race... unless it can engage in a critical reassessment and a critical engagement with these issues, I would continue to value it, but also see it as limited in terms of what can be accomplished under socialism. I am very excited by these commitments to socialism that are not emerging, because they have been there, in Latin America for some time. But there are different experiences of the world, there are different ways of being in the world, that the best traditions of the West are unable to understand. It has been outside their experience and without a willingness to acknowledge that and an openness to think through what that might mean, I am always cautious about what this socialist vision might mean for those not of the 'West'. 